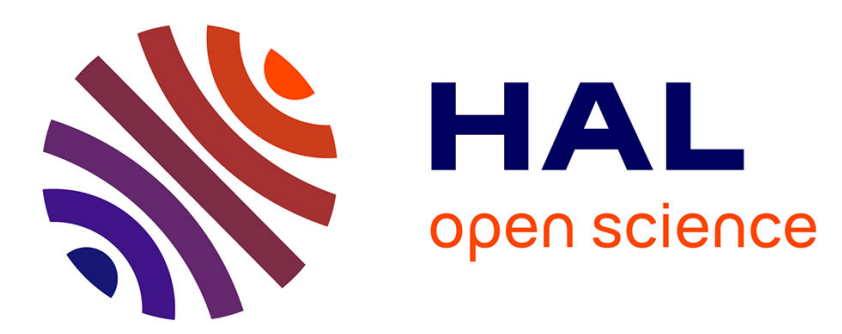

\title{
Amino Acid Supplementation Prevents the Loss of Appetite for Casein in Old Lou/Cjall Rats
}

Ghislaine Nzang Nguema, Elisabeth Debras, Jean Grizard, Josette Alliot

\section{To cite this version:}

Ghislaine Nzang Nguema, Elisabeth Debras, Jean Grizard, Josette Alliot. Amino Acid Supplementation Prevents the Loss of Appetite for Casein in Old Lou/Cjall Rats. Experimental Gerontology, 2007, 42 (7), pp.652. 10.1016/j.exger.2007.02.001 . hal-00499009

\section{HAL Id: hal-00499009 https://hal.science/hal-00499009}

Submitted on 9 Jul 2010

HAL is a multi-disciplinary open access archive for the deposit and dissemination of scientific research documents, whether they are published or not. The documents may come from teaching and research institutions in France or abroad, or from public or private research centers.
L'archive ouverte pluridisciplinaire HAL, est destinée au dépôt et à la diffusion de documents scientifiques de niveau recherche, publiés ou non, émanant des établissements d'enseignement et de recherche français ou étrangers, des laboratoires publics ou privés. 


\section{Accepted Manuscript}

Amino Acid Supplementation Prevents the Loss of Appetite for Casein in Old Lou/Cjall Rats

Ghislaine Nzang Nguema, Elisabeth Debras, Jean Grizard, Josette Alliot

PII:

S0531-5565(07)00031-9

DOI:

10.1016/j.exger.2007.02.001

Reference:

EXG 8309

To appear in:

Experimental Gerontology

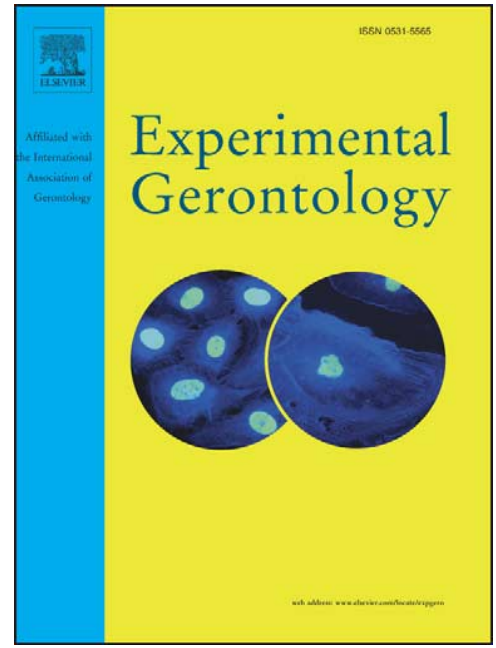

Received Date: $\quad 8$ September 2006

Revised Date: $\quad 1$ February 2007

Accepted Date: $\quad 2$ February 2007

Please cite this article as: Nguema, G.N., Debras, E., Grizard, J., Alliot, J., Amino Acid Supplementation Prevents the Loss of Appetite for Casein in Old Lou/Cjall Rats, Experimental Gerontology (2007), doi: 10.1016/j.exger. 2007.02.001

This is a PDF file of an unedited manuscript that has been accepted for publication. As a service to our customers we are providing this early version of the manuscript. The manuscript will undergo copyediting, typesetting, and review of the resulting proof before it is published in its final form. Please note that during the production process errors may be discovered which could affect the content, and all legal disclaimers that apply to the journal pertain. 


\section{Amino Acid Supplementation Prevents the Loss of Appetite for Casein}

\section{in Old Lou/Cjall Rats}

Ghislaine Nzang Nguema, Elisabeth Debras *, Jean Grizard* and Josette Alliot ${ }^{2}$ Université Blaise Pascal, Clermont-Ferrand, France and * Institut National de la Recherche Agronomique, Unité de Nutrition et Métabolisme Protéique, 63122 Ceyrat, France

Running Title: Protein Intake in Old Rats

Requests for reprints and correspondence should be addressed to:

3 Pr. Josette Alliot

4 Laboratoire de Neuroendocrinologie du Vieillissement,

5 Complexe Scientifique des Cézeaux, Université Blaise Pascal,

624 rue des landais

763177 Aubière Cedex, France

8 Tel: +33473407476

9 Fax: +33473407903

20 E.mail: josette.alliot@univ-bpclermont.fr

1

22 This work was supported by research grant (ATC Vieillissement) from the Institut National de la 3 Santé et de la Recherche Médicale. 
25

26

\section{Abstract}

A deleterious reduction of casein intake occurring earlier in males than in females had been previously observed in old lou/cjall rats. On the contrary, protein intake was observed to be maintained in old males when they were offered whey protein. Present studies were designed to investigate the effect of dietary casein modification on protein decrease. In two lifelong studies, male and female Lou/Cjall rats were tested every four months in order to study protein intake depending on the protein available: casein, whey protein or casein supplemented with an amino acid mixture (SC). In subsequent cross-sectional studies, young, adult, middle-aged and old rats were successively fed with casein, casein supplemented either with leucine or with alanine or with glycine. Supplementing casein with an amino acid mixture both globally increased protein intake and allowed old males to maintain a high rate of protein intake. In cross sectional experiments, no effect of supplementation was seen in the young group. In older animals, the greatest effect was seen when casein was supplemented with alanine or glycine, independently of sex and age. We therefore, concluded that supplemented casein is more beneficial for old rats than casein alone, probably by increasing amino acid availability. We hypothesize that alanine could act through its effect on gluconeogenesis.

Keywords: Aging, casein, self-selection, amino acid supplementation, Lou/Cjall rats. 


\section{Introduction}

Changes in macronutrient intake as a function of age and sex were highlighted by previous studies carried out on Lou/Cjall rats, a lean strain which had been proposed as a model of healthy aging (Alliot et al. 2002). As rats grew old, a shift in energetic nutrient preference from carbohydrates to fat and a decrease in protein intake occurred (Veyrat-Durebex and Alliot 1997). Moreover, a sexual dimorphic protein intake appears in old age. After 16 months of age, females were shown to maintain the protein intake rate around $12 \%$ of total energy intake until 28 months, while males dramatically decreased it. The reduction of protein intake observed in aged rats was concurrent with body weight loss, skeletal muscle atrophy and decreased plasma concentrations of IGF1 (Veyrat-Durebex et al., 1999).

Young and mature rats are capable of selecting a sufficient amount of protein to satisfy amino acid requirements (White et al. 2000). We previously showed that this ability is manifested in old age: old and senescent rats increased their protein intake in response to the specific needs induced by protein deprivation (Boghossian et al., 2002) and by treatment with dexamethasone ((Nzang Nguema et al., 2005). Therefore, it has been highlighted that a strong reduction of protein intake with age cannot be attributed to a loss of regulation of protein intake with age.

So far, we used casein as the source of protein. The adequacy of casein for young rats had been shown in numerous studies. Its composition specifically the ratio of essential to non-essential amino acids is adequate to ensure protein synthesis in developing rats (James and Treloar, 1981; Krajcovicova and al., 1993; Semon et al., 1987). However, aging may induce changes in amino acid requirements in senescent animals. Moreover, studies on protein digestion rates and amino acid absorption led to the concept of slow and fast dietary proteins (Boirie et al., 1997). Casein is a slow dietary protein, which in young rats, results in a significant weight gain and in parallel assists greatly in nitrogen retention when compared to the corresponding crystalline amino-acid mixture (Daenzer et al., 2001). In elderly subjects, a fast protein such as whey protein might be more beneficial than casein in order to limit protein loss (Dangin et al., 2003). Thus, casein may become 


\section{ACCEPTED MANUSCRIPT}

an inadequate source of protein for old animals, inducing an innate avoidance/aversion behaviour, a protective mechanism against imbalanced food sources (Harper et al., 1970; Koehnle et al., 2003). This hypothesis was supported by recent data; using various sources of proteins, we showed a reduction of consumption of casein but not of whey protein in old rats (Nzang Nguema et al., 2004). Consequently, the experiments presented here were designed to study the effect of dietary casein modification. First, casein was supplemented with an amino acid mixture, in order to obtain a composition close to that of whey protein. Two male and female cohorts were simultaneously studied and the free choice of supplemented casein (SC) throughout life was compared to the free choice of casein (C) and whey protein (W)

Second, using cross sectional studies, we studied the effect of supplementation of casein with specific amino acids on casein intake, in order to identify specific amino acid requirement of old animals.

\section{2- Materials and Methods}

\section{2-1 Animals}

The rat facilities and protocol were approved by the appropriate ethics committee of the University. Male and female rats of the inbred Lou/Cjall strain (Blaise Pascal University, France) were used. The first Lou rats of Wistar origin (Bazin, 1990) were imported into the University of Louvain (Belgium) as a single pair in 1937-1941. The Lou/Cjall rats were bred in our laboratory for 15 years. The biological and physiological changes occurring during aging have been previously described (Alliot et al., 2002). Briefly, the most interesting characteristics of this strain are the longevity (median life span is 29 months in males and 33-34 months in females), the absence of obesity and the absence of severe pathologies. Basic phenomena of aging, expressed as body weight loss and muscular atrophy as well as energy and protein intake declines, appear after 18 months of 


\section{ACCEPTED MANUSCRIPT}

96

97

98

99

100

101

102

103

104

105

106

107

108

109

110

111

112

113

114

115

116

117

118

119

120

121

age in males and are delayed in females. After 24 months of age, a markedly greater rate of body and muscle mass loss seems to trigger the onset of senescence.

Lou/Cjall rats were housed in pairs in plastic cages $(40 / 20 / 15 \mathrm{~cm})$ and placed in a temperature-controlled room $\left(22 \pm 1{ }^{\circ} \mathrm{C}\right)$ on a 12 :12h light dark cycle (lights off at $\left.2000 \mathrm{~h}\right)$. At the time when rats were not employed for experiments, they were granted free access to both water and standard pellets U.A.R. A04 (Usine d'Alimentation Rationnelle, Villemoison, France). The energy content of standard pellets was $2.9 \mathrm{kcal} / \mathrm{g}$ and consisted of $17.5 \%$ of soluble fish protein concentrate, $3 \%$ of fat, and $49.8 \%$ of carbohydrate.

\section{2-2 Experimental Design}

Two separate experiments, including several stages, were successively conducted.

\section{2-2-1 Experiment 1}

The experimental design is depicted in Figure 1. $52 \mathrm{Lou} / \mathrm{Cjall}$ rats were employed for the experiment. At the start of the experiment, the rats were 3 month-old for cohort 1 (12 males and 12 females) and 12 month-old for cohort 2 (14 males and 14 females). They were first adapted to the powder diet and then habituated to the self-selection procedure. During the habituation periods, casein (C: Louis François, Saint-Maur, France) and whey protein (W: Cofranlait, France) were used.

Habituation to Powder Diet: All rats were maintained on a powdered chow diet for two weeks in order to familiarise them to the experimental apparatus and to the new form of the diet. The chow diet composition was closed to the U.A.R. A.04 composition (metabolisable energy was 3.31 $\mathrm{Kcal} / \mathrm{g}$ ). It consisted of $17 \%$ protein, 3\% fat (lard), 70\% carbohydrate (cornstarch: Cerestar 12018 Louis François Exploitation, France) 5\% salt mixture (UAR, 205b ${ }^{3}$ ), 4\% cellulose powder and $1 \%$ vitamins $\left(\mathrm{UAR}, 200^{4}\right)$. Food-filled $(20 \pm 2 \mathrm{~g})$ glass cups anchored in the back of the cage with a pierced stainless steel plate were used. To allow a habituation to the taste and odour of the two 


\section{ACCEPTED MANUSCRIPT}

122 different proteins, two powder diets differing only in their protein content ( $\mathrm{C}$ or $\mathrm{W})$ were

123 simultaneously available

124 At the end of the habituation, no spillage of food was seen.

125 Habituation to the Self-Selection Procedure: All rats were habituated to the self-selection

126 procedure during an 18-days period. Protein, fat and carbohydrates were placed in three separate

127 cups. The fat component $(7.88 \mathrm{kcal} / \mathrm{g})$ contained $91 \%$ lard and $2 \%$ sunflower oil. The carbohydrate

128 component $(3.34 \mathrm{kcal} / \mathrm{g})$ consisted of $85 \%$ cornstarch and $8 \%$ commercial grade sucrose. Salt

129 mixture (4\%), vitamins (1\%) and cellulose powder $(2 \%)$ were added to each macronutrient.

130 The offered protein change every 2 days according to 2 different patterns: $C, W$ or $W, C$.

131 Then, a first test period (12 days) was introduced. Each protein was successively given for 6

132 consecutive days to each animal either in the order $\mathrm{C}, \mathrm{W}$ or $\mathrm{W}, \mathrm{C}$.

133

134 Afterwards, when rats reached the age of 7, 11, 15, 19,23, 27 for cohort 1 and the age of 16, 20, 24

135 and 28 months for cohort 2, they were tested again. They were submitted to the self-selection

136 procedure and to test period as described above. However, during the test, an additional period of 6

137 days was introduced at the end of the test. During this additional period, casein supplemented with

138 an amino acid mixture (15\% of free amino-acids) was used as source of protein. Amino acid

139 mixture was used so that the supplemented casein (SC) mimicked whey protein composition (Table

140 1).

141

142 Body weight and macronutrient intakes were recorded daily during habituation and test periods.

143 At the age of 27-28 months, only 10 males (38.5\%) and 15 females (61.5\%) were successfully able

144 to survive. The first deaths occurred at 23 months (5 males and 2 females in cohort 1; 3 males and 3

145 females in cohort 2), as previously described.

146

147

\section{2-2-2 Experiment 2}




\section{ACCEPTED MANUSCRIPT}

148 Experiment 2 was conducted to determine if old rats selected greater amount of casein, when it was

149 supplemented with individual amino acids. The experimental design is depicted in Figure 2. In

150 experiment $2 \mathrm{a}$, casein was supplemented either with leucine or with alanine, used as isonitrogenous

151 control. Indeed, alanine can be considered as inert, and may be used as "placebo" (Chambon-

152 Savanovitch et al., 1999). In experiment $2 b$, the effect of supplementation of casein with alanine

153 was compared to supplementation with glucose and with glycine, taken as isonitrogenous control.

154 Animals:

15544 male and 48 female Lou/Cjall rats were used. At the onset of the experiments, they were

156 distributed into four age groups: young [2 month-old; 14 males $(123 \mathrm{~g} \pm 2.8)$ and 12 females $(104 \mathrm{~g}$

$157 \pm 1.5)$ ], mature [7 month-old; 12 males $(265 \mathrm{~g} \pm 3.4)$ and 11 females $(178 \mathrm{~g} \pm 3.1)]$, middle-aged [16

158 month-old; 12 males $(314 \mathrm{~g} \pm 8.2)$ and 12 females $(199 \mathrm{~g} \pm 4.2)$ ], old [24 month-old; 8 males $(296.4 \mathrm{~g}$

$159 \pm 15.5)$ and 11 females $(190 \mathrm{~g} \pm 3.8))]$.

\section{Experiment $2 a$}

161 The total duration of the experiment 2 a was 50 days, proceeding in three stages as already

162 described: habituation to the powder diet, habituation to the self-selection procedure and test

163 period. As only casein was used as the source of protein, only one chow diet was offered in the first

164 stage of habituation and only casein was given during habituation to self-selection. The last four

165 days of habituation were used as the basal period for casein intake.

166 The test lasted for 18 days. At that time, animals were respectively 3 month-old for young group,

167 and 8, 17 and 25 month-old for respectively mature, middle-aged and old groups. Three proteins

168 were used: casein (C), casein supplemented with $4.5 \%$ of leucine (CLeu) and casein supplemented

169 with $4.5 \%$ of alanine (CAla). Each protein was given during 6 consecutive days, according to the

170 following schedule: C, CLeu, CAla for one third of animals; CLeu, CAla, C for the second third;

171 and CAla, C, CLeu, for the last third. Rats of all age groups were distributed into each pattern of

172 protein distribution.

173 Experiment $2 b$ 


\section{ACCEPTED MANUSCRIPT}

174 Three months later, the adult rats used in experiment 2a were tested again. Animals were

175 maintained for 3 weeks in the self-selection procedure with casein as a source of protein before the

176 test began. The last four days of habituation were used as the basal period for casein intake.

177 The test lasted for 24 days. At that time, animals were 11, 20 and 28 month-old for respectively

178 mature, middle-aged and old groups. Four proteins were used: casein, casein supplemented with

$1794.5 \%$ of glucose (Cglu), casein supplemented with $4.5 \%$ of alanine (CAla) casein supplemented

180 with $4.5 \%$ of glycine (CGly). Each protein was given during 6 consecutive days, according to the

181 following schedule: $C, C g l u$, CAla, CGly for a quarter of animals; Cglu, CAla, CGly, C for the

182 second quarter; CAla, CGly, C, Cglu for the third quarter; and CGly, C, Cglu, CAla for the last

183 quarter. Animals of all age groups were distributed into each pattern of protein distribution.

184 Body weight and macronutrient intakes were recorded daily.

185

186

188

189

190

191

192

193

194

195

196

197

198

199

200

\section{2-3 Statistical Analyses}

All data are expressed as mean \pm SEM. As the rats were housed in pairs, the statistical unit for food intake was generally the pair of rats except when a rat died because its counterpart remained alone in the cage until the end of experiment.

Experiment 1: The data of the last four days of each test period were considered for statistical analysis. A One-way ANOVA (effect of sex) for repeated measures (age and protein choices) with significance at $\mathrm{p}<0.05$ was used. When a significant overall effect was detected, differences between means were assessed with a mean least square test.

Experiment 2: The data of the last four days of habituation (basal intake) and of each test period were considered for statistical analysis. A Two-way ANOVA (effect of age and sex) for repeated measures with significance at $\mathrm{p}<0.05$ was performed to evaluate the effect of supplementation on casein intake. ANOVA was followed by a mean least square test for a-posteriori means comparison.

\section{3- Results}


3-1 Experiment 1: Life Long Studies

203

204

205

206

207

208

209

210

211

212

213

214

215

216

217

218

220

221

\section{Body Weight and Caloric Intake (Table 2)}

Body weight and caloric intake were in agreement with previously obtained data (Alliot et al. 2002). In the two cohorts, a loss of body weight appeared in old males but not in females. Concerning the age-related changes in caloric intake, females increased their caloric intake from the age of 23 months onwards. Thus, the differences in caloric intake between males and females were strongly reduced by 27 months of age.

\section{Diet Selection and Effect of the Type of Protein (C or W)}

As rats grew old, they underwent a noticeable change in their diet composition (cohort 1: F (12, $84)=16.4 ; \mathrm{p}=0.0001 ;$ cohort $2: \mathrm{F}(8,48)=11.1 ; \mathrm{p}=0.0001)$ : rats consumed more fat and less carbohydrates and protein (Figure 3).

The type of protein $(\mathrm{C}$ or $\mathrm{W})$ did not induce significant changes either in total caloric intake or in fat and $\mathrm{CHO}$ preference. However, it modified protein consumption. Overall, rats ate more casein than whey protein but this preference appeared clearly only in the female group, mainly in the young age (mean intake: $17.2 \% \pm 1.4$ of casein versus $10.9 \% \pm 0.5$ of whey protein. The pattern of protein consumption differed as a function of protein and gender: (protein $X$ sex $X$ age $(\mathrm{F}(6,42)=2.1$; $\mathrm{p}=0.07$ ). The preference for casein disappeared from 15-16 months of age in female groups whereas a preference for whey protein appeared in males (10\% versus $5 \%$ in the cohort 1$)$. The

same results were observed in cohort 2: preference for whey protein in males, no preference for casein in females from 16 months of age. Therefore, the reduction in protein intake seen in old male groups after 15-16 months of age appeared only with casein and not with whey protein.

\section{Effects of the Casein Supplementation}

Initially, when the rats had access to casein supplemented with an amino acid mixture (Figure 4), they took a greater amount of protein, compared to casein alone $(F(1,7) \geq 48.4 ; p \geq 0.0001 ; \quad$ mean 


\section{ACCEPTED MANUSCRIPT}

228 intake cohort $1: 7.1 \pm 0.4 \mathrm{kcal}$ versus $5 \pm 0.4 \mathrm{kcal} ; 20.3 \% \pm 1$ versus $14.2 \% \pm 1$; cohort $2: 4.4 \pm 0.3$

229 versus $2.1 \pm 0.3 \mathrm{kcal} ; 12.1 \% \pm 0.8$ versus $7.5 \% \pm 0.8$ ). Secondly, the age-related changes in 230 protein intake underwent modification, mainly in males (Interaction age $x$ sex $x$ protein $(\mathrm{F}(5,44)=$ $2312.9 ; \mathrm{p}=0.03)$ in cohort $1 ;(\mathrm{F}(3,26)=3 ; \mathrm{p}=0.04)$ in cohort 2$)$. The consumption of $\mathrm{SC}$ was maintained 232 at a higher level than casein and remained constant from 15-16 months of age in males, at the level 233 of whey protein consumption. Females selected identical amounts of casein and SC except at the 234 age of 15 and 19 months in cohort 1 . As was the case for casein alone, females preferred SC to 235 whey protein. This preference for SC versus whey protein disappeared at only 23-24 months in the 236 two cohorts (instead of 15-16 months for casein alone).

237 The nature of the protein did not influence the total energy intake $(\mathrm{F}(2,12)=1.2 \mathrm{~ns})$.

238

239

240

241

242

243

\section{3-2 Experiment 2.}

\section{3-2-1 Experiment $2 a$}

At the end of habituation, diet composition chosen by young rats was obviously different from that chosen by other groups (Table 3). Young rats mainly selected CHO whereas all other groups mainly chose fat as a source of energy. Large inter-groups variations in protein intake were observed in females.

The basal intake of calories was dependent on age $\mathrm{F}(6,146)=72 ; \mathrm{p}>0.0001)$, being high in young group and low in old groups.

\section{Effect of Supplementation on Total Protein Intake}

In the young groups, no effect of supplementation appeared $(\mathrm{F}(2,22)=3 \mathrm{~ns})$. However, in the older groups, the amount of casein consumed was higher $(F(2,56)=35 ; \mathrm{p}=0.0001)$ when it was supplemented. The greatest effect was seen with alanine as a supplement, independent of the sex and age of animals (Figure 5).

\section{3-2-2 Experiment 2b}




\section{ACCEPTED MANUSCRIPT}

255 Anova showed an effect of age $(\mathrm{F}(2,28)=6.4 ; \mathrm{p}=0.005)$ and an effect of protein $(\mathrm{F}(3,84)=31 ; \mathrm{p}$

$256=0.0001)$. Total protein intake was greater in 11 month-old groups compared to older groups.

257 Casein supplemented with glucose had no effect on protein consumption whereas supplementation

258 with alanine and glycine increased casein consumption in the same way (Figure 6).

\section{4-General Discussion}

261 When casein was offered, the well-established age and sex-related changes in protein consumption 262 of Lou/Cjall rats (Alliot et al. 2002) were seen in the two cohorts. There was a clear gender 263 difference, with females maintaining their protein intake around 10-12\% whereas the males showed 264 a strong decrease after 15 months of age. This late decrease was prevented by the use of whey 265 protein, according to previously obtained results (Nzang Nguema et al., 2004). When casein was supplemented either with amino acid mixture or with a particular amino acid, mature and old rats chose it in greater amount than casein alone. More specifically, experiment 1 showed that adding an amino acid mixture to casein counteracted the strong decrease of casein consumption in males as

they grew old and maintained the preference for casein longer in the life in females. These data suggest that supplemented casein, like whey protein, must be greatly beneficial for old rats than casein alone and consequently, they support the hypothesis that casein may be an imbalanced or an inadequate amino acids source for old rats, inducing an aversion behaviour.

As already mentioned, the adequacy of casein for young rats had been shown in numerous studies but amino acid requirement is probably dependent on age (Young et al., 1994; Reeds, 2000). The nutritional classification between dispensable, conditionally indispensable and indispensable amino acids could be inaccurate for senescent organisms and the ability to synthesise the conditionally essential amino can decrease with age.

278 However, as casein was supplemented with a mixture of free amino acid, both the amount and the speed of absorption of amino acids were modified. We showed (Nzang Nguema 2005) that plasma amino acid concentration rose as soon as within 15 minutes after an intake of a meal supplying CS.

281 Increasing amino acid availability via oral intake of mixed amino acid (Paddon-Jones et al., 2004; 


\section{ACCEPTED MANUSCRIPT}

282

283

284

285

286

287

288

289

290

291

292

293

294

295

296

297

Volpi et al., 1999) increased amino acids transport into muscle cells in elderly healthy humans and stimulated protein synthesis. Therefore, supplementing casein can improve an efficient use of exogenous amino acids by skeletal muscle. Volpi et al. (2003) showed that effective supplements have to include essential amino acids. The analysis of the mixture added to the casein in experiment 1 suggested that leucine was the limiting amino acid. Indeed, the branched-chain amino acids (BCAA) support numerous metabolic processes and the potential for BCAA to participate in each of these metabolic processes appears to be proportional to their availability (Layman, 2003). More specifically, leucine is the only amino acid able to reproduce the effect of a mixture of amino acids on muscle protein synthesis. Moreover, old rats are less sensitive to its effect (Dardevet et al., 2000) but an acute meal supplementation with leucine is sufficient to restore postprandial stimulation of muscle protein synthesis (Dardevet et al., 2002). Since a small deficiency in a limiting amino acid should be able to decrease protein selection (Hrupka et al., 1997), we hypothesised that leucine supplement could restore the protein intake of old rats. Surprisingly, in experiment 2a, even though leucine induced a slight stimulation of casein intake in adult and old groups, the greatest effect was seen with alanine. Alanine is a dispensable amino acid, considered as being inert (ChambonSavanovitch et al., 1999). It has no effect on protein synthesis in old rats (Dardevet et al., 2002). Nevertheless, it is possible that a greater intake of any amino acid resulting in a greater plasmatic concentration may have stimulated a greater level of oxidation.

However, another possible mechanism can be evoked. On one hand, alanine is an important precursor for hepatic gluconeogenesis (Ahlborg et al., 1974; Ruderman, 1975). It represents one of the major amino acids released from skeletal muscle and converted to glucose in the liver (Garber et al., 1976). Most amino acids are precursors for alanine synthesis in muscle (Garber, 1976), specifically leucine (Holecek, 2001) and glycine (Garber et al., 1976; Chambon-Savanovitch, 1999; Volpi et al., 2003). Glycine is also a precursor of serine, another gluconeogenic substrate. On the other hand, glucose intolerance developed in aged animals. Spontaneous intake of carbohydrates is strongly reduced in old rats compared to young ones, and fat plays a prominent role as an energetic fuel in the diet. It is likely that there is an increased contribution of alanine to glycogen repletion 


\section{ACCEPTED MANUSCRIPT}

and that the source of alanine in the muscles of adult and old animals is mainly amino acids precursors. However, in the present study, supplementing casein with glucose did not stimulate casein intake. This last data could support a reduction in the glucose transport and utilisation with aging.

Although casein supplementation with a particular amino acid was ineffective in young rats, it had an identical stimulating effect in adult and old rats. A first explanation can lie in the use of cross-sectional studies. As the three groups were compared on the basis of chronological age whereas physiological aging may differ from those age cohorts, cross-sectional experiments are not appropriate, compared to life long experiments, to study changes with advancing age. Secondly, in behavioural as well as in metabolic studies, attempts to identify a unique amino acid requirement are likely to be unsuccessful. Multiple results could be achieved for the same amino acid, depending on the interaction of various factors such as the amount and the nature of protein and nonprotein energy ingested (Wolfe, 2002). Moreover, there are interactions between individual amino acids, which result in the concentrations of one amino acid influencing the oxidation rate and hence the requirement of others (Millward and Rivers, 1988). Particularly, increased intake of leucine increased plasma leucine concentration but decreased isoleucine and valine availability (Harper and Benjamin, 1984).

In conclusion, the loss of appetite for protein observed in old age can be counteracted by supplementation with a balanced mixture of amino acids, probably by increasing the amino acids availability and followed by the ability to efficiently use them. Moreover, the unexpected stimulating effect of supplementation with alanine suggests an age-related increase in gluconeogenic substrates requirements. Nevertheless, further studies are needed to address this last issue.

\section{Acknowledgements}


338 We thank Dr R. Taylor and Dr D. Bechet for proofreading the English version of this article.

\section{References}

Ahlborg G., Felig P., Hagenfeldt L., Hendler R., Wahren J., 1974. Substrate turnover during

prolonged exercise in man. Splanchnic and leg metabolism of glucose, free fatty acids, and amino acids. J Clin Invest. 53(4), 1080-90.

Alliot, J., Boghossian, S., Jourdan, D., Veyrat-Durebex, C., Pickering, G., Meynial-Denis, D.,

Gaumet, N., 2002. The LOU/c /jall as an animal model of healthy aging? J. Geront. Biol. Sci. 57

Bazin, H. The Louvain (LOU) rats., 1990. Rat Hybridomas and rats Monoclonal Antibodies, CRC press, Cleveland, OH. 43-51.

Boirie, Y., Dangin, M., Gachon, P., Vasson, M.P., Maubois, J. L., Beaufrère, B., 1997. Slow and Physiol. 94, 14930-14935.

Boghossian, S., Nzang, Nguema G., Jourdan, D., Alliot, J., 2002. Old as mature LOU/c/jall rats 


\section{ACCEPTED MANUSCRIPT}

Chambon-Savanovitch, C., Felgines, C., Farges, M. C., Raul, F., Cezard, J.P., Davot, P., Vasson, M.P., Cynober, L.A., 1999. Comparative study of glycine, alanine or casein as inert nitrogen sources in endotoxemic rats. J. Nutr. 129 (10), 866-1870.

Daenzer, M., Petzke, K.J., Bequette, B.J., Metges, C.C., 2001. Whole-body nitrogen and splanchnic amino acid metabolism differ in rats fed mixed diets containing casein or its corresponding amino acid mixture. J. Nutr.131(7),1965-72.

Dangin, M., Guillet, C., Garcia-Rodenas, C., Gachon, P., Bouteloup-Demange, C., Rieffers Magnani, K., Fauquant, J., Ballèvre, O., Beaufrère, B., 2003. The rate of protein digestion affects protein gain differently during aging in humans.. J. physiol. 549(2), 635-644.

Dardevet, D., Sornet, C., Balage, M., Grizard, J., 2000. Stimulation of in vitro rat muscle protein synthesis by leucine decreases with age. J. Nutr. 130 (11), 2630-2635.

Dardevet, D., Sornet, C., Bayle, G., Prugnaud, J., Grizard, J. (2002) Postprandial stimulation of muscle protein synthesis in old rats can be restored by a leucine-supplemented meal. J. Nutr. 132 (1), 95-100.

Garber, A. J., 1976. Alanine and glutamine synthesis and release from skeletal muscle. II. The precursor role of amino acids in alanine and glutamine synthesis. J. Biol. Chem. 251(3), 836-843.

Garber, A.J., Karl, I.E., Kipnis, D.M., 1976. Alanine and glutamine synthesis and release from skeletal muscle. I The Glycolysis and amino acid release. J. Biol. Chem. 251(3), 826-835.

Harper A.E., Benevenga, N.J., Wolhlueter, R.M., 1970. Effects of ingestion of disproportionate amounts of amino acids. Physiol. Rev. 50, 428-558. 
391 Harper, A.E., Benjamin, E., 1984. Relationship between intake and rate of oxidation of leucine and 392 alpha-ketoisocaproate in vivo in the rat. J. Nutr. 114 (2), 431-440.

393

394 Holecek, M., 2001. The BCAA-BCKA cycle: its relation to alanine and glutamine synthesis and 395 protein balance. Nutr. 17, 70.

396

Hrupka, B.J., Lin, Y.M., Gietzen, D.W., Rogers, Q.R., 1997. Small changes in essential amino acid 398 concentrations alter diet selection in amino acid-deficient rats. J. Nutr. 127 (5), 777-784.

James, K.A., Treloar, B.P., 1981. Incorporation of (14C) leucine into protein of perfused liver of 401 rats fed diets containing casein or lactalbumin. J. Nutr. 111 (10), 1797-1804.

402

403

Koehnle, T.J., Russell, M.C., Gietzen D.W., 2003. Rats rapidly reject diets deficient in essential 404 amino acids. J. Nutr. 133, 2331-2335.

405

Krajcovicova-Kudlackova, M., Ozdin, L., Bobek, P., 1993. Protein synthesis in growing and adult 407 rats on casein and gluten nutrition. Physiol. Res. 42 (1), 17-22.

408

Layman, D.K., 2003. The role of leucine in weight loss diets and glucose homeostasis. J. Nutr. 133

410 (1), 261S-267S.

Millward, D.J., Rivers, J.P., 1988. The nutritional role of indispensable amino acids and the 413 metabolic basis for their requirements. Eur. J. Clin. Nutr. 42 (5), 367-393.

414

415 Nzang Nguema, G., Grizard, J., Alliot, J.,2004. The reduction of protein intake observed in old rats 416 depends on the type of protein. Exper. Gerontol. 39, 1491-1498. 
418 Nzang Nguema, G., Boghossian, S., Grizard, J., Dardevet, D., Alliot, J., 2005. Effect of 419 dexamethasone treatment on protein intake in adults and old Lou/c/jall rats. Mech. Ageing Dev. $420 \quad 126,655-663$;

421

Paddon-Jones, D., Sheffield-Moore, M., Zhang, X.J., Volpi, E., Wolf, S.E., Aarsland, A., Ferrando, 423 A.A., Wolfe, R.R., 2004. Amino acid ingestion improves muscle protein synthesis in the young and elderly. Am J Physiol Endocrinol Metab. 286 (3), E321-E328.

Reeds, P.J., 2000. Dispensable and indispensable amino acids for humans. J. Nutr. 130, 1835S1840S.

Ruderman N.B., 1975. Muscle amino acid metabolism and gluconeogenesis. Ann. Rev. Med. 26, 245-58.

Semon, B.A., Leung, P.M. B., Rogers, Q.R., Giezten, D.W., 1987. Effect of type of protein on food intake of rats fed high protein diets. Physiol. Behav. 44, 451- 458.

Veyrat-Durebex, C., Alliot, J., 1997. Changes in pattern of macronutrient intake during aging in male and female rats. Physiol. Behav. 62 (6), 1273-1278.

Veyrat-Durebex, C., Gaudreau, P., Coxam, V., Gaumet, N., Alliot, J., 1999. Peripheral injection of growth hormone stimulates protein intake in aged male and female Lou rats. Am. J. Physiol. Endocrinol. Metab., 276, E1105-E1111. 
444 Endocrinol. Metab., 277, E513-E520.

445

446 Volpi, E., Kobayashi, H., Sheffield-Moore, M., Mittendorfer, B., Wolfe, R.R., 2003. Essential

447 amino acids are primarily responsible for the amino acid stimulation of muscle protein anabolism in

448 healthy elderly adults. Am. J. Clin. Nutr. 78 (2), 250-258.

449

450 White, B.D., Porter, M.H., Martin, R.J., 2000. Effects of age on the feeding response to moderately

451 low dietary protein in rats. Physiol. Behav. 68(5), 673-681.

452

453 Wolfe, R.R.,2002. Regulation of muscle protein by amino acids. J Nutr. 132 (10), 3219S-3224S.

454

455 Young, V.R., El-Khoury A.E., Sanchez, M., Castillo, L., 1994. The biochemistry and physiology of

456 protein and amino acid metabolism, with reference to protein nutrition in Protein Metabolism

457 During Infancy. Niels C. \&R. Raiha (Eds). Vol. 33. Raven Press. New York. 


\section{LEGENDS OF FIGURES}

459

460

461

462

463

464

465

466

467

468

469

470

471

472

473

474

475

476

477

478

479

480

481

482

483

484

Figure 1:

Experiment 1-Procedure

A: 3 month-old (cohort 1) and 12 month-old (cohort 2) male and female rats were submitted to habituation periods (habituation to powdered complete diet and to self selection procedure (18 jours). During test, casein (C) and whey protein.(W) were successively available.

B: Four months later, and after, each four months, all rats were submitted to self selection procedure. An additional test period was introduced, during which supplemented casein was given.

\section{Figure 2}

Experiment 2- Procedure

Experiment $2 A$ : Four groups of age (2, 7, 16 and 24 months) were habituated to powdered diet and to self selection procedure. During test, casein alone and casein supplemented either with leucine (Cleu) or with Alanine (Cala) were successively available.

Experiment 2B: 3 months later, adult, middle-aged and old rats were tested again. During test, casein alone and casein supplemented either with glucose (CGlu) either with alanine (CAla) or with glycine (Cgly) were successively and randomly proposed.

\section{Figure 3:}

Age-related changes in diet composition as a function of advancing age and of dietary protein in cohort 1(upper panels) and cohort 2 (lower panels)

During test, casein and whey protein are successively proposed during six days. Each point represents the mean percentage of total caloric intake for protein $(\mathrm{P})$, fat, and carbohydrates $(\mathrm{CHO})$ during the last four days of the test periods. 


\section{ACCEPTED MANUSCRIPT}

485

486

487

488

489

490

491

492

493

494

495

496

497

498

499

500

501

502

503

504

505

506

507

508

509

510

511

512

513

514

515

516 a posteriori-tests:

a: $\mathrm{p}<0.05$ vs 3 months $\mathrm{b}$ : $\mathrm{p}<0.05$ vs 7 months;

c: $\mathrm{p}<0.05$ vs $11-12$ months $\mathrm{d}: \mathrm{p}<0.05$ vs $15-16$ months

$* \mathrm{p}<0.05$ vs casein $\neq \mathrm{p}<0.05$ vs male group

Figure 4 : Protein intake of male and female Lou/Cjall rats as a function of advancing age and protein available.

Data points indicate the mean 24-h protein selection in Kcal (mean \pm SEM) when rats were given C, W or SC.

a posteriori-tests: $\quad$ b: $\mathrm{p}<0.05$ vs7 months; $\quad \mathrm{c}: \mathrm{p}<0.05$ vs $11-12$ months $\mathrm{d}: \mathrm{p}<0.05$ vs $15-16$ months $\quad$ e: $\mathrm{p}<0.05$ vs $19-20$ months $* \mathrm{p}<0.05$ vs casein $\quad \$ \mathrm{p}<0.05$ vs whey

Figure 5: Experiment 2a: Casein intake during the test period in young rats (upper panel) and in adult, middle-aged and old rats (lower panel).

Data points represent mean $( \pm$ SEM) caloric intake of casein during the last four days of habituation (Cbasal) or during the last four days of presentation of each protein (C, CLeu and CAla) during the test. The intake of casein alone was similar during the test compared to basal period.

a posteriori tests: a: $\mathrm{p}<0.05$ vs 8 month-old; b: $\mathrm{p}<0.05$ vs 17 month-old;

$* \mathrm{p}<0.05$ vs casein $\$ \mathrm{p}<0.05$ vs Cleu

Figure 6: Experiment 2b: Casein intake during the test period.

Data points represent mean $( \pm$ SEM) caloric intake of casein during the last four days of habituation (Cbasal) or during the last four day of presentation of each protein (C, Cglu, CGly and CAla) during the test period. The intake of casein alone was similar during the test compared to basal period.

a posteriori tests: $\quad$ a: $\mathrm{p}<0.05$ vs 11 month-old; b: $\mathrm{p}<0.05$ vs 20 month-old; 
TABLE 1:

Amino acid composition of the mixture, whey protein, casein ${ }^{1}$ and $S C^{2}$

$\%$ of amino-acid in mixture $\quad \%$ of amino acid in protein diet

\begin{tabular}{|c|c|c|c|c|}
\hline & \multirow{3}{*}{\multicolumn{2}{|c|}{ Whey Protein $^{1}$}} & \multirow[b]{2}{*}{ Casein $^{1}$} & \multirow[b]{2}{*}{$\begin{array}{l}\text { Supplemented } \\
{\text { casein }(\mathrm{SC})^{2}}\end{array}$} \\
\hline & & & & \\
\hline \multicolumn{3}{|c|}{ Essential amino-acids (\%) } & & \\
\hline Histidine & 1.26 & 1.9 & 2.9 & 2.8 \\
\hline Isoleucine & 3.38 & 5.0 & 5.1 & 4.8 \\
\hline Leucine & 30.00 & 12.3 & 9.2 & 12.3 \\
\hline Lysine & 6.55 & 9.7 & 8.0 & 7.8 \\
\hline Methionine & 1.34 & 2.0 & 2.9 & 2.7 \\
\hline Phenylalanine & 2.43 & 3.6 & 5.1 & 4.9 \\
\hline Threonine & 3.56 & 5.3 & 4.3 & 4.2 \\
\hline Valine & 3.25 & 4.8 & 6.6 & 6.5 \\
\hline Tryptophane & 7.97 & 2.1 & 1.1 & 2.1 \\
\hline \multicolumn{5}{|c|}{ Nonessential amino-acids (\%) } \\
\hline Alanine & 3.12 & 4.6 & 3.0 & 3 \\
\hline Arginine & 1.91 & 2.8 & 3.6 & 3.9 \\
\hline Aspartate & 4.60 & 6.8 & 7.1 & 6.5 \\
\hline Asparagine & 3.08 & 4.6 & 4.9 & 4.6 \\
\hline Glutamate & & 10.9 & 23.7 & 20.1 \\
\hline Glutamine & 3.95 & 5.9 & 6.2 & 5.9 \\
\hline Glycine & 1.34 & 2.0 & 1.8 & 1.7 \\
\hline Serine & 3.30 & 4.9 & 5.7 & 5.3 \\
\hline Tyrosine & 2.34 & 3.5 & 5.6 & 5.1 \\
\hline Proline & & 4.1 & 10.3 & 8.7 \\
\hline Cysteine & 16.60 & 2.9 & 0.5 & 2.9 \\
\hline
\end{tabular}

${ }^{1}$ Amino-acid composition of whey protein and casein were obtained from INRA.

${ }^{2} \mathrm{SC}$ was composed of $85 \%$ casein and $15 \%$ amino-acid mixture 
TABLE 2:

Body weight and caloric intake of male and female LOU/Cjall before the start of experimental periods in experiment 1

\begin{tabular}{|c|c|c|c|c|c|}
\hline & & \multicolumn{2}{|c|}{ Males } & \multicolumn{2}{|l|}{ Females } \\
\hline \multirow{8}{*}{ Cohort 1} & Age (months) & BW (g) & $\begin{array}{c}\text { Caloric intake } \\
\text { (Kcal/24h) }\end{array}$ & BW (g) & $\begin{array}{c}\text { Caloric intake } \\
\text { (kcal/24h) }\end{array}$ \\
\hline & 3 & $180.9 \pm 3.6$ & $49.1 \pm 1.3$ & $119.0 \pm 2.2^{z}$ & $34.9 \pm 1.2^{\prime \prime}$ \\
\hline & 7 & $277.4 \pm 4.0^{\mathrm{a}}$ & $45.6 \pm 1.9$ & $170.3 \pm 3.4^{\mathrm{az}}$ & $33.0 \pm 1.6^{*}$ \\
\hline & 11 & $301.7 \pm 8.4^{\mathrm{ab}}$ & $42.6 \pm 1.7$ & $189.8 \pm 2.9^{\mathrm{a} x}$ & $31.7 \pm 1.5^{\sharp}$ \\
\hline & 15 & $301.0 \pm 12.0^{\mathrm{ab}}$ & $42.2 \pm 1.3$ & $193.2 \pm 4.1^{\mathrm{ab}}$ & $32.1 \pm 0.8^{\sharp}$ \\
\hline & 19 & $297.9 \pm 18.9^{\text {ab }}$ & $41.5 \pm 0.9^{\mathrm{a}}$ & $203.2 \pm 4.1^{\mathrm{ab}}$ & $30.5 \pm 0.9^{*}$ \\
\hline & 23 & $302.3 \pm 28.9^{\mathrm{ab}}$ & $40.0 \pm 1.5^{\mathrm{a}}$ & $193.1 \pm 8.6^{\mathrm{ab}^{8}}$ & $33.4 \pm 1.6^{*}$ \\
\hline & 27 & $285.2 \pm 11.1$ acdef & $44.1 \pm 2.0$ & $189.8 \pm 4.1^{\mathrm{ab}}$ & $34.8 \pm 1.8^{*}$ \\
\hline \multirow{5}{*}{ Cohort 2} & 12 & $284.7 \pm 7.2$ & $44.0 \pm 1.4$ & $178.9 \pm 3.4^{*}$ & $30.4 \pm 1.5^{\sharp}$ \\
\hline & 16 & $296.3 \pm 7.6$ & $41.1 \pm 1.4$ & $184.9 \pm 3.5^{*}$ & $30.2 \pm 1.2^{*}$ \\
\hline & 20 & $286.8 \pm 12.7$ & $41.4 \pm 3.1$ & $182.3 \pm 4.7^{*}$ & $34.3 \pm 2.3^{*}$ \\
\hline & 24 & $278.0 \pm 11.0^{\mathrm{cdc}}$ & $43.9 \pm 3.2$ & $178.0 \pm 7.5^{x}$ & $35.2 \pm 2.9^{*}$ \\
\hline & 28 & $267.1 \pm 19.2^{\text {oddf }}$ & $40.6 \pm 3.4$ & $185.7 \pm 6.0^{\sharp}$ & $36.2 \pm 5.8^{\mathrm{dd}}$ \\
\hline
\end{tabular}

${ }^{*} \mathrm{p}<0.05$ vs male group;

a $\mathrm{p}<0.05$ vs 3 -month-old ; ${ }^{\mathrm{b}} \mathrm{p}<0.05$ vs 7 -month-old $;{ }^{\mathrm{c}} \mathrm{p}<0.05$ vs $11-12$ months

${ }^{\mathrm{d}} \mathrm{p}<0.05$ vs $15-16$ months; ${ }^{\mathrm{e}} \mathrm{p}<0.05 \mathrm{vs} 19-20$ months; ${ }^{\mathrm{f}} \mathrm{p}<0.05$ vs $23-24$ months. (a-posteriori tests) 


\section{TABLE 3:}

Percentage of macronutrients and total caloric intake (Kcal/24h) before test in experiment 2a .

\begin{tabular}{|c|c|c|c|c|c|c|c|c|}
\hline & \multicolumn{4}{|c|}{ Males } & \multicolumn{4}{|c|}{ Females } \\
\hline & Young & Adult & Middle-aged & Old & Young & Adult & Midde-aged & Old \\
\hline \%Casein & $24.3 \pm 0.7$ & $13.0 \pm 1.7^{\mathrm{a}}$ & $13.5 \pm 3.1^{\mathrm{a}}$ & $9.7 \pm 1.5^{\mathrm{a}}$ & $13.9 \pm 1.8^{\#}$ & $23.0 \pm 3.4^{\mathrm{a}^{f}}$ & $14.8 \pm 2.4$ & $18.0 \pm 3.8^{\mathrm{b}}$ \\
\hline$\%$ Fat & $16.0 \pm 1.9$ & $66.0 \pm 1.7^{\mathrm{a}}$ & $60.0 \pm 2.7^{\mathrm{a}}$ & $60.3 \pm 3.7^{\mathrm{a}}$ & $18.1 \pm 2.7$ & $47.0 \pm 4.0^{\mathrm{aft}}$ & $63.2 \pm 3.5^{\mathrm{ab}}$ & $60.0 \pm 4.7^{\mathrm{ab}}$ \\
\hline$\%$ carbohydrate & $60.2 \pm 2.2$ & $21.0 \pm 2.2^{\mathrm{a}}$ & $26.5 \pm 2.4^{\mathrm{a}}$ & $30.0 \pm 5.1^{\mathrm{a}}$ & $68.7 \pm 2.5$ & $30.0 \pm 6.5^{\mathrm{a}}$ & $22.0 \pm 2.7^{\mathrm{a}}$ & $22.0 \pm 4.5^{\mathrm{a}}$ \\
\hline Total caloric intake & $48.7 \pm 0.5$ & $41.3 \pm 1.6$ & $44.3 \pm 1.0$ & $39.0 \pm 2.1^{\mathrm{c}}$ & $36.0 \pm 1.7^{\sharp}$ & $34.8 \pm 1.8^{\#}$ & $31.8 \pm 1.2^{\#}$ & $31.1 \pm 1.3^{\#}$ \\
\hline
\end{tabular}

A posteriori tests: ${ }^{\#} \mathrm{p}<0.05$ vs male group; ${ }^{\mathrm{a}} \mathrm{p}<0.05$ vs young $;{ }^{\mathrm{b}} \mathrm{p}<0.05$ vs adult; ${ }^{\mathrm{c}} \mathrm{p}<0.05$ vs middle-aged 


\section{Nzang et al EXG- FIGURE 1}

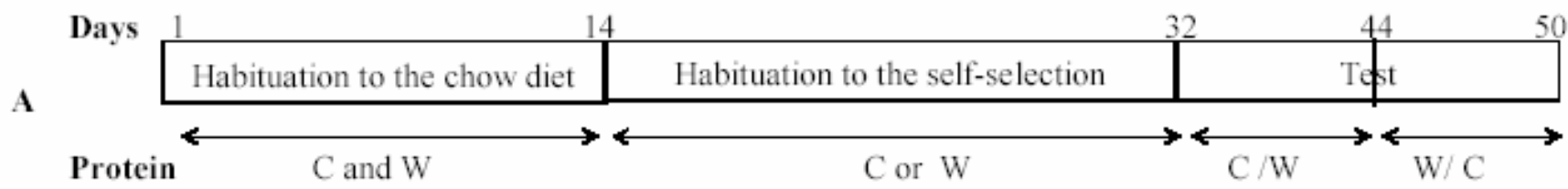

B

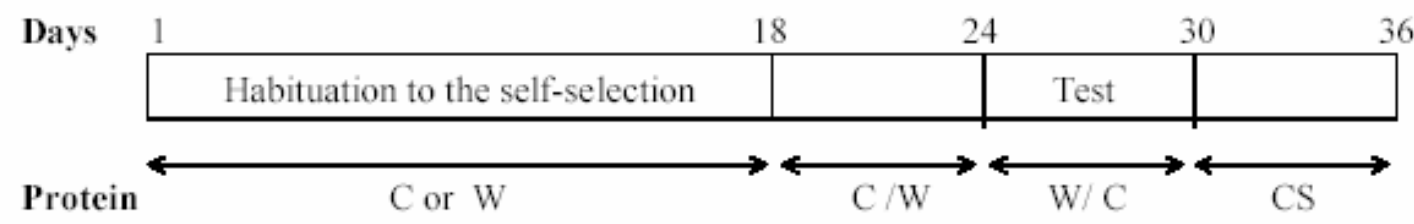


Nzang et al EXG Figure 2

Experiment 2A

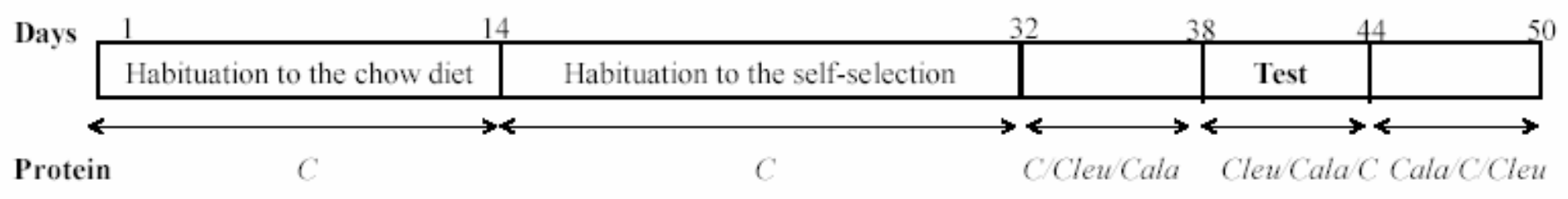

Experiment 2B

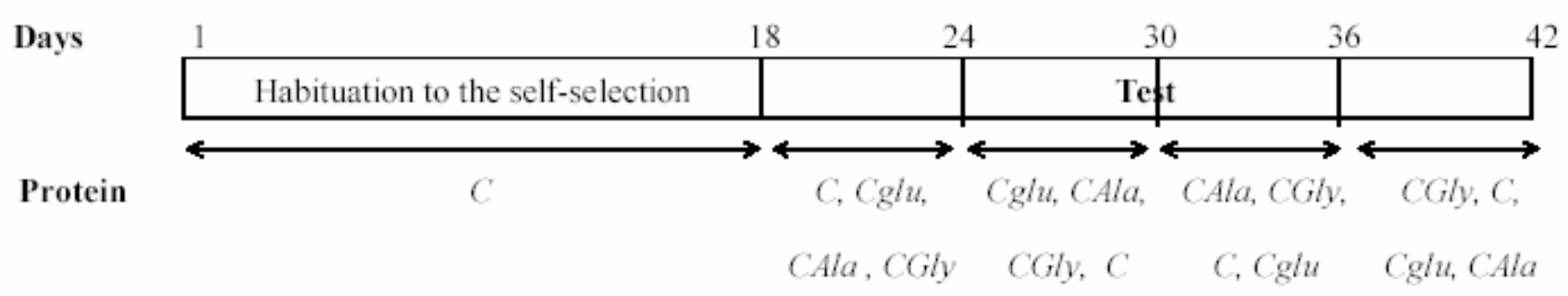


Figure 3

Males

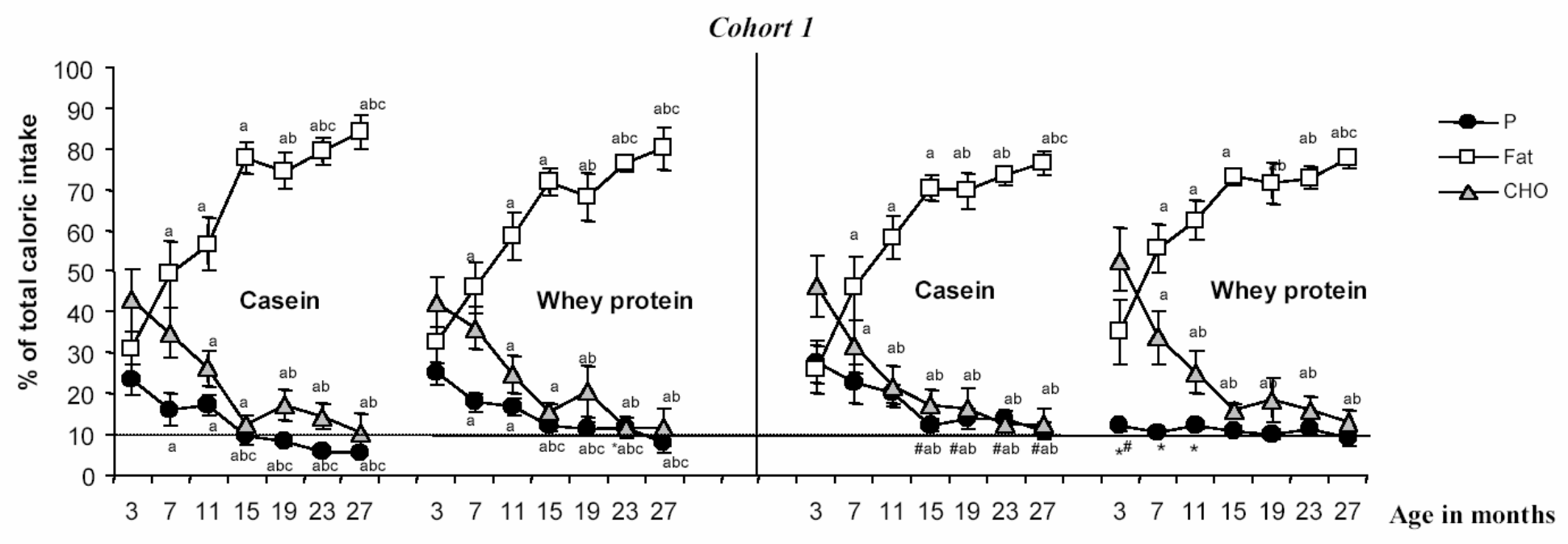

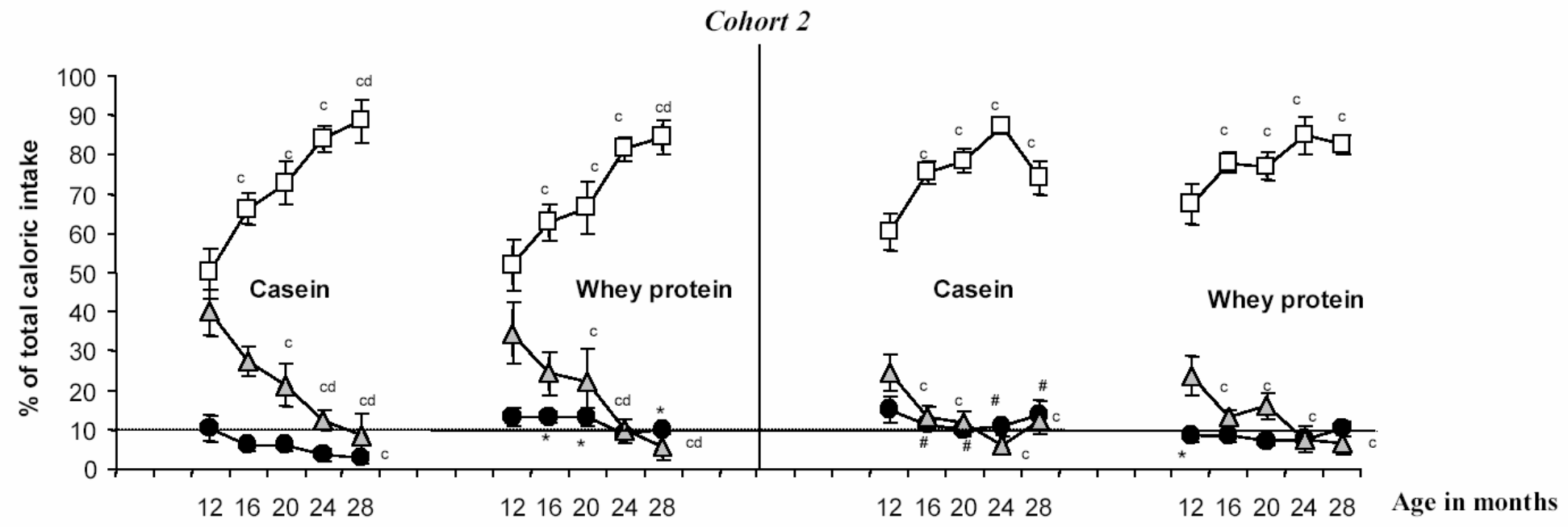




\section{Figure 4}

Cohort 1
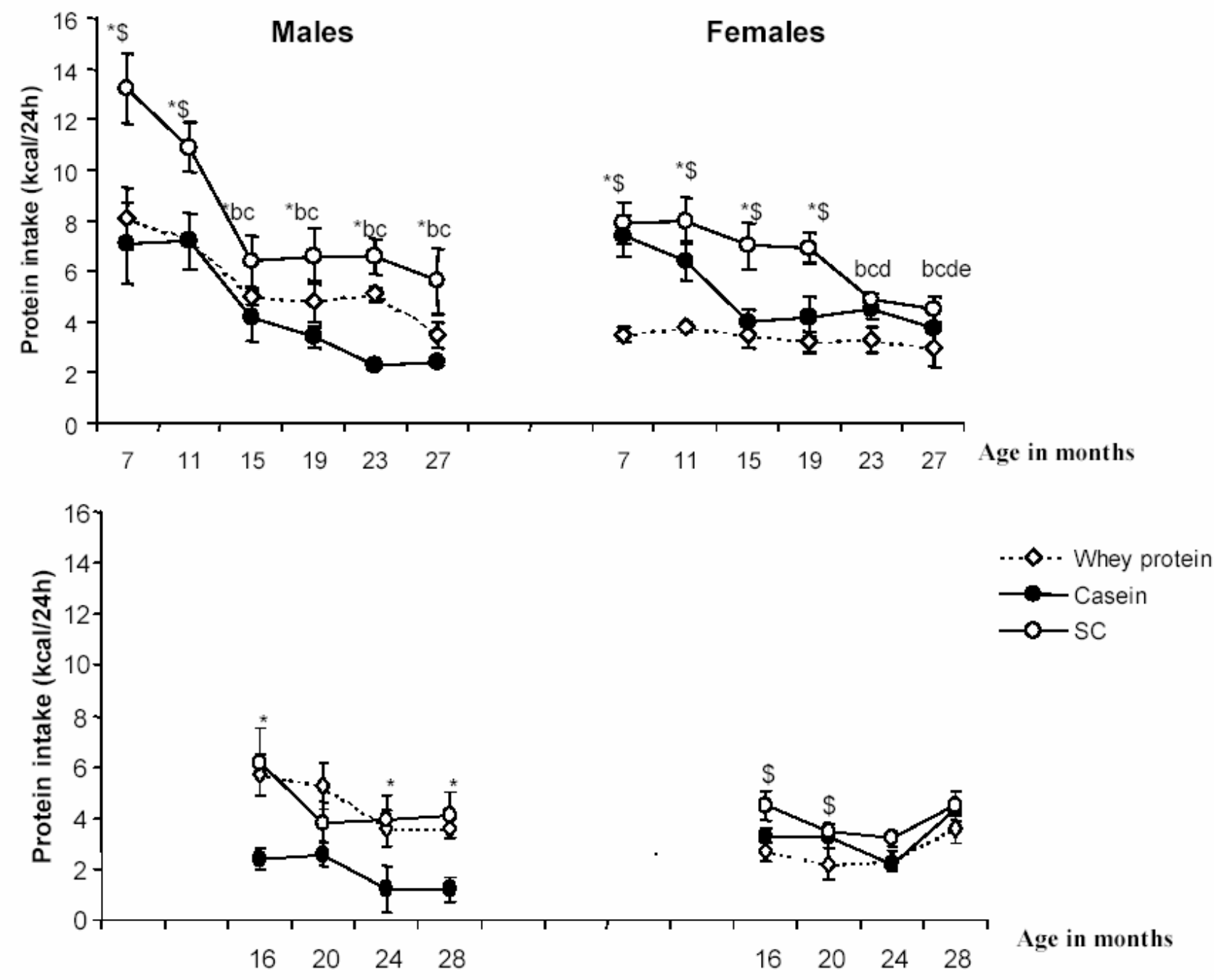


\section{Figure 5}
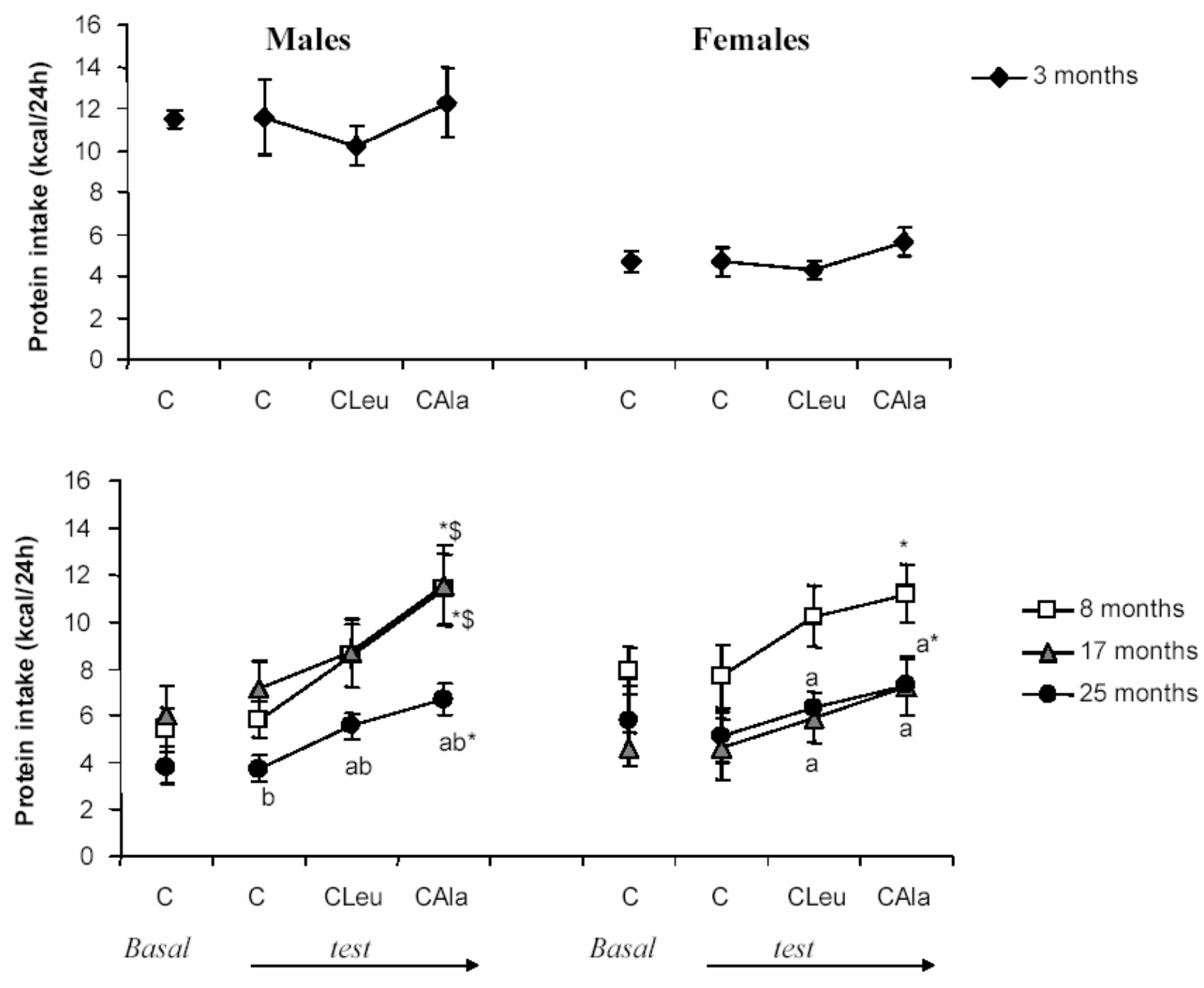


\section{Figure 6}

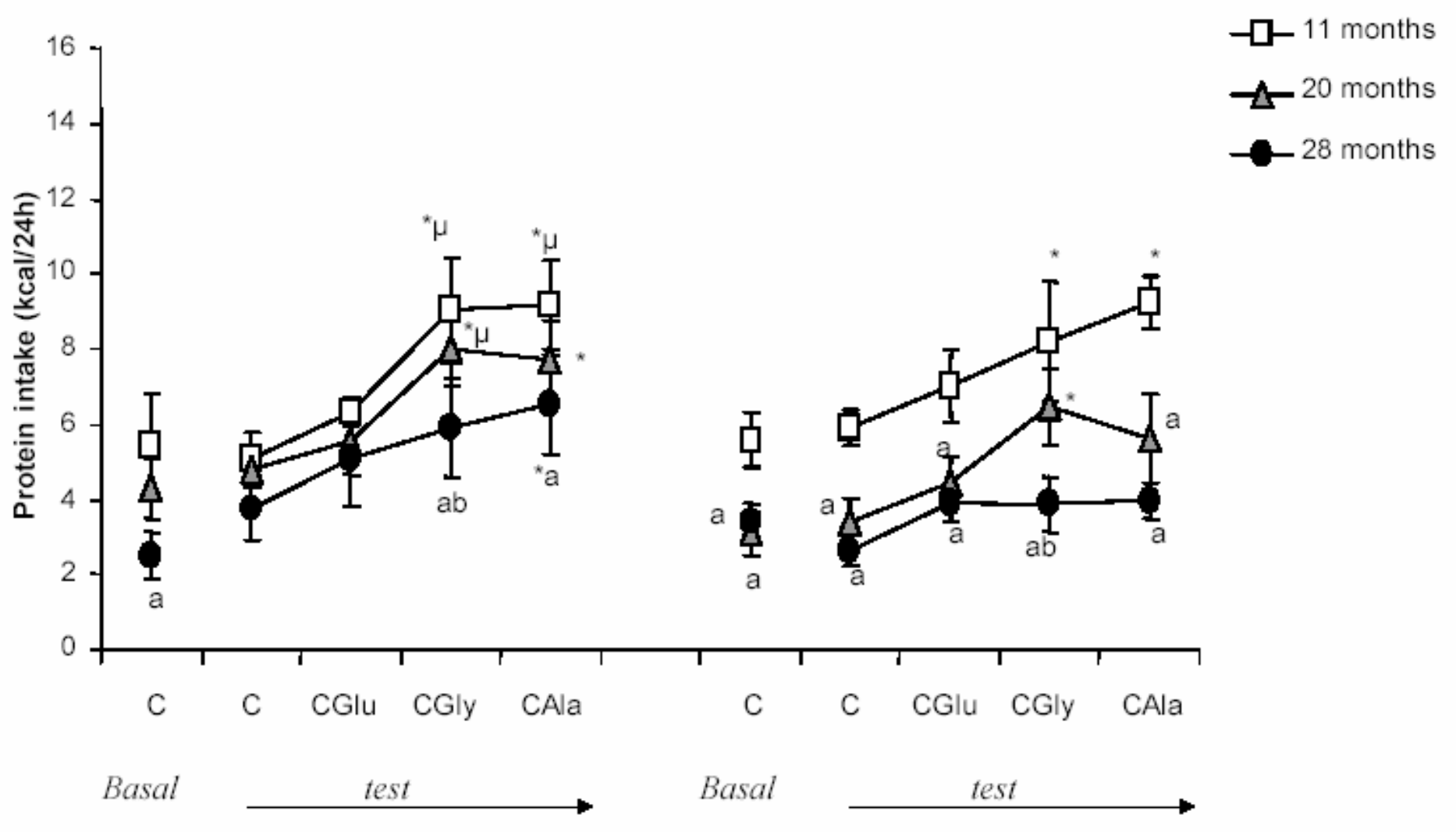

